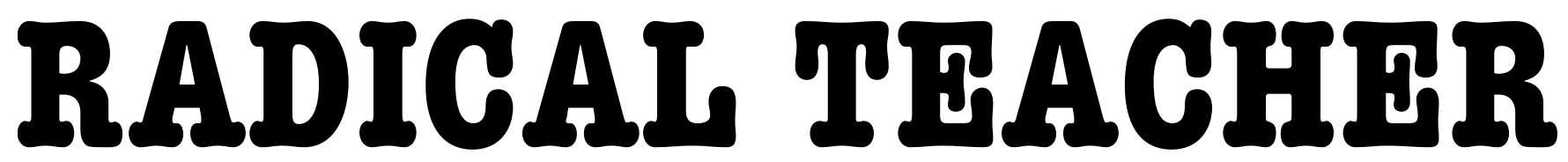

A SOCIALIST, FEMINIST, AND ANTI-RACIST JOURNAL ON THE THEORY AND PRACTICE OF TEACHING

\title{
Cape Town, South Africa, 2003
}

by Frinde Maher

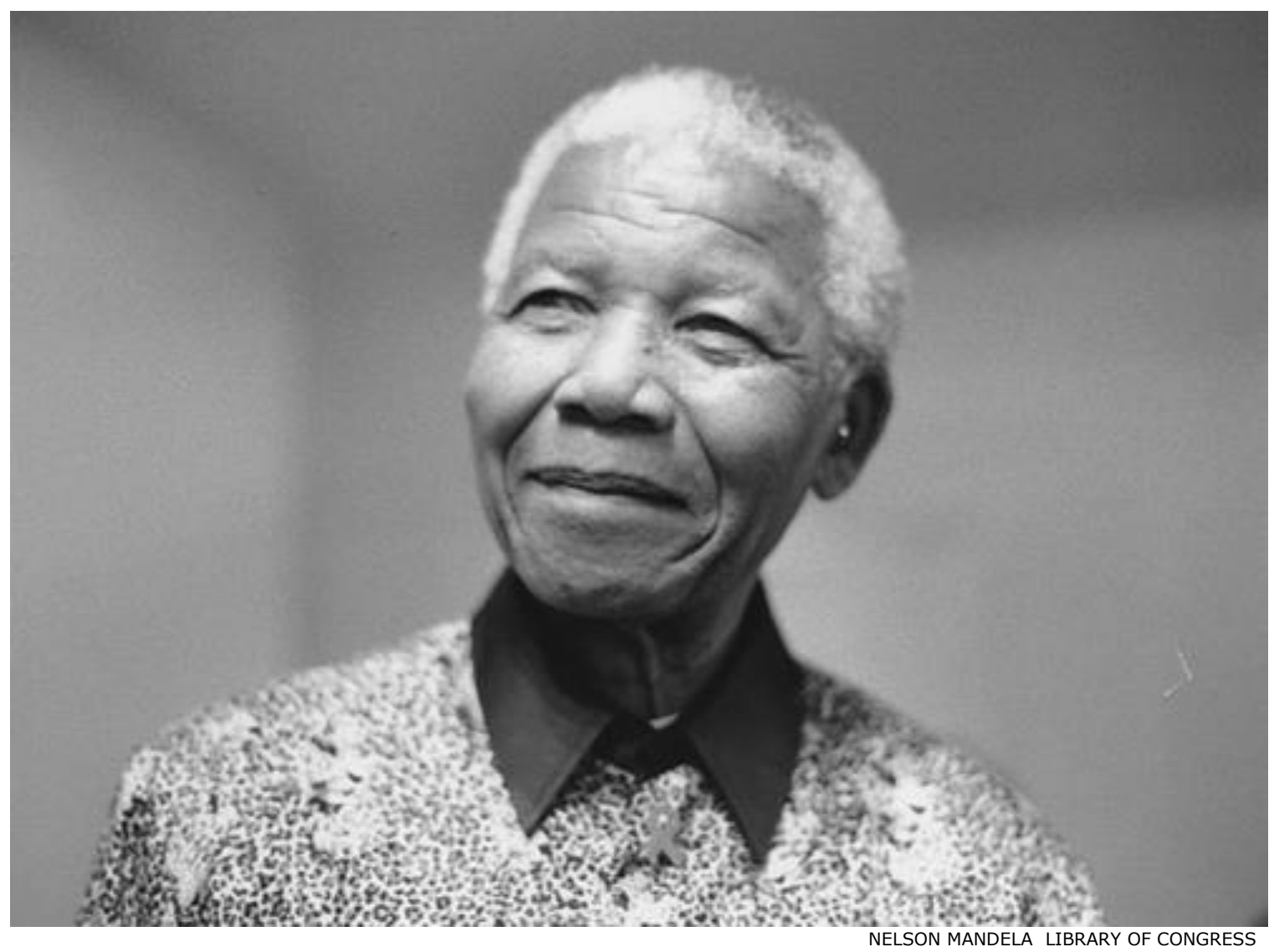


W hen Norman Levy returned to South Africa in 1990, after 25 years of exile in London, Nelson Mandela had just been released from prison. Norman couldn't wait to get home, even though the position of the African National Congress (ANC), and his own status as a formerly jailed, then exiled ANC activist, was still unclear. When he got off the plane, he was greeted by a man in a police uniform who said, "Are you ANC? Then come with me." Masking his trepidation, he followed the man through the crowd to a closed door. When the door opened, what he saw in front of him was not a jail cell, or a police desk, but a big room full of balloons, tables full of food, and a welcoming committee full of smiles and cheers. "Welcome home!" they said.

My husband John and I heard this story from Norman when they were reunited in New York, fifteen years after they had become friends during John's sabbatical in London in 1984. I was a sometime former anti-apartheid activist, one of many who marched in support of demonstrations and worked on divestment issues. Norman spent four years in jail and twenty-five years in exile. Having given much of his life over to a successful, nonviolent revolution, he could experience victory after decades of commitment, a life-defining struggle with a happy ending. What a contrast to the way things were in the United States! At home, democracy, racial and economic justice, seemed hopelessly unattainable in our lifetimes. Here was this new society, poised to embark on a parallel journey, on the move when our own society was so bogged down.

John and I went to South Africa for the first time in 1999 to visit Norman and his New Yorker wife Carole in Cape Town. We took snacks and ANC leaflets to the enthusiastic lines of people waiting to vote in the second national election. They were not as long as the worldfamous and much photographed lines for the first election in 1994, but they were long enough. We went back again in 2001. We began to meet a few people at the University of the Western Cape (UWC) outside of Cape Town, where Norman had begun teaching in the Political Science Department. Then, in 2003, we decided to go and live there for six months.

Under Apartheid there had been four racial classifications, White, Indian, Coloured and Black, representing a strict hierarchy of privilege and access. Every single aspect of life, from housing to education to health care to employment to drivers' licenses to the regulation of leisure time, was divided by racial classification. Of these groups Black Africans were and are by far the largest, making up $80 \%$ of the population. From the anti-apartheid struggle many Americans are familiar with images of the townships, where the bulk of the poorest of the Black population continue to live in shacks of cardboard and corrugated iron. Near the vast stretches of the townships in Cape Town lie sections of small houses once allocated to the Coloureds, giving way to the slightly larger bungalows of the Indians and working class Whites. Of course middle and upper class Whites lived, and still do, in all the comfortable and attractive townhouses, mansions and apartment buildings overlooking the harbor or Table Mountain.
The University of the Western Cape is a formerly "Coloured" university that used to have mainly Coloured students and mostly white faculty. By 2003, and still today, UWC has more Coloured faculty (although still mostly white), and an almost all Black and Coloured student body. It is located in a working class town called Belleville, half an hour outside the city, beyond the airport and amid a desiccated landscape of scrub pines, lowrise factory buildings and Coloured and Indian housing estates. The campus itself is a large and rambling assemblage of stucco buildings surrounded by green grass, an attractive oasis in the desert.

Some of the people we met in 2001 at UWC worked at a research laboratory called the Education Policy Unit (EPU), a government funded organization administering

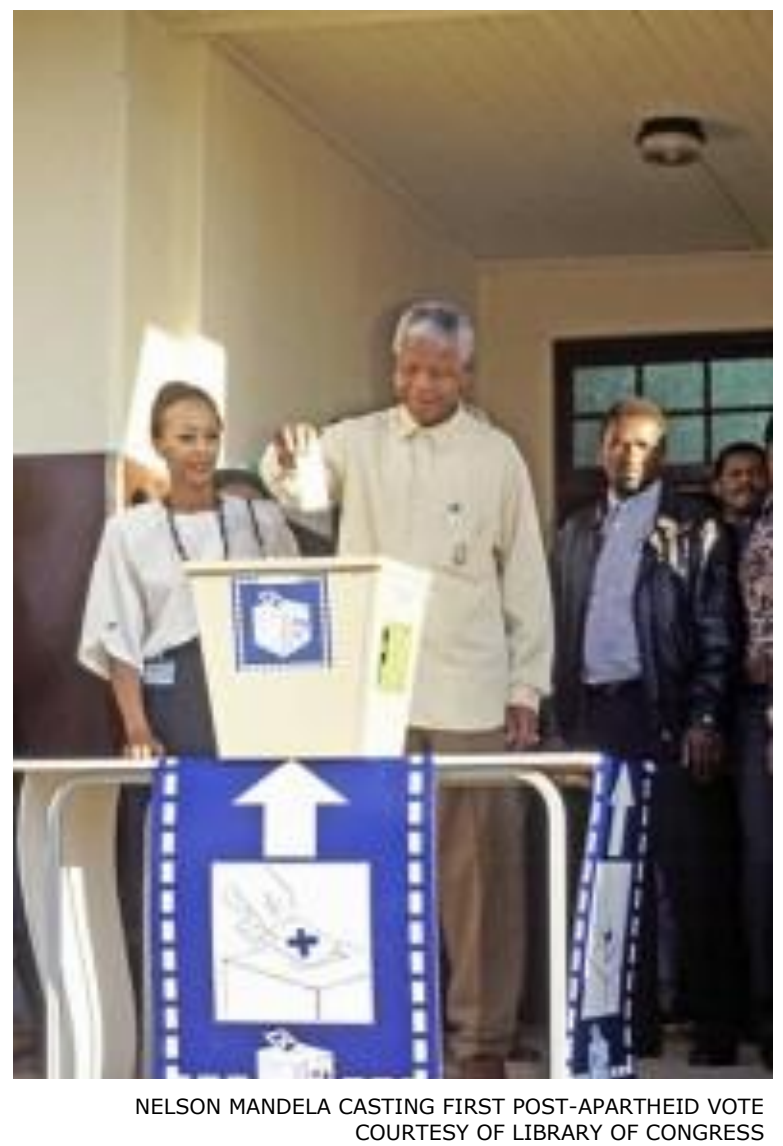

various grants to transform the apartheid education system from the ground up. How to make a functioning, open and equitable school and university system out of four distinct and profoundly unequal educational ghettoes? When the opportunity arose for me to take part of my sabbatical abroad in 2003, I decided to accept an invitation to be a Visiting Fellow at the EPU. (John was finishing a book on economic theory and would find colleagues in local economic departments.) My own work in the United States at the time was studying the excruciatingly slow pace of integrating American university faculties by race and gender, and I hoped to find out more about the processes by which post-apartheid South African universities were building their new faculties and student bodies. 
According to the plan I made with the director of the EPU, my role would be to help people with their various research grants, give several talks, and coach the few graduate students getting MA's there in educational administration. My major responsibility quickly became working with a Coloured colleague, a young woman I'll call Betty Taylor, on one of her grants. The director thought she needed help in conceptualizing and conducting her research, as well as in her administrative duties. As it turned out, she was a whiz at all of these tasks, and needed my support less than she needed some help in dealing with an extremely unreasonable workload. She became a close colleague and long-term friend.

What did I expect at the EPU? Most of all, I told myself, I was looking forward to participating in any research they were doing on, say, hiring of new faculty under the new dispensation. My stance was eagerness above all. "How can I help?" Not only did I not question many of my assumptions, I was often unaware of their existence-they came into view only to be overturned or reframed into something else.

I had no idea of the extent of the indignities of apartheid. One Monday morning I stopped by the desk of the Unit's administrative assistant, an affable Coloured man named Charlton. I had just climbed Table Mountain that weekend, and wanted to boast about it. "Have you ever climbed it, Charlton?"

\section{I had no idea of the extent of the indignities of apartheid.}

"No, Coloureds weren't allowed on Table Mountain." Not allowed on a simple mountain trail. He went on to tell me about the typical background of apartheid housing policies: his family's removal from their apartment in one of the coastal towns outside the Cape of Good Hope to a hastily constructed and now falling down township in the middle of nowhere, ironically labeled, "Ocean View." They still live there, with no hope of collecting the damages due them by the government for the loss of their seaside community.

In subsequent encounters I began to learn about the severe limitations of my own experiences of race, racism and white privilege (about which I had considered myself an expert.) One day at lunch a colleague explained to me the new policy of "deracialization"- "We try not to use racial designations any more, or notice racial differences." I swallowed my reaction, that at home not seeing "race" might be itself racist. Of course they are trying to get rid of racial classifications. Who am I to say any different? Was my radical American take on race really more "advanced?" Or was I just not getting the situation well enough? Was I right or wrong to think that they were not "ready" to ignore race? Of course, this is an unresolvable dilemma: as long as the realities of discrimination and disadvantage exist, there is no "right" way to deal with it. Erasing "race" is hypocritical; acknowledging it risks perpetuating it.
In any case, I soon learned that in practice this deliberate erasure of racial classifications was not at all a linguistic or as we might say a "discourse" issue, but rather an urgent, universal political concern. Every single law and regulation, from the national to the provincial to the local level, needed to be rewritten, because for every law and regulation there was a different version for each of the four racial classifications. And of course, the whole educational system was based on them, with the so-called "Model $\mathrm{C}^{\text {" }}$ schools, formerly reserved for Whites, at the top. The pressure to integrate such places was exacerbated at every stage by the low educational levels of Coloured and especially Black African children. Apartheid had denied them anything more than basic literacy, and sometimes not even that.

\section{In short, Table Mountain was the least of it.}

I also had to face the irrelevance of much of my previous experiences in the field of education. My academic specialty is pedagogy, the classroom construction of knowledge. I had written articles and a book about how to bring students into conversations by finding out what they already knew and working with their own experiences to build broader understandings.

I was supposed to give a talk on Feminist Pedagogy, my field, at the EPU. Yet when I tried to enact it rather than just talk about it, by asking the researchers about their own pedagogies of engagement with students, I was told, "Just tell us what you know. What do you do at home?" I lectured for an hour, to friendly stares of polite incomprehension, about the challenges of leaving off lecturing in favor of student-centered teaching. After all, I told myself, why would they want to spend a precious lunch hour listening to my questions about them?

In the event, over time, my concerns with studentcentered teaching jibed with some of their worries about the very low level of preparedness of many of their students and how they could reach them, to teach them the kinds of research methods they would need for an MA. Most of the staff at the EPU taught classes as well as ran their research projects. They agreed with me about the need to listen to students, but they also helped me see the limitations of my well-honed, student-centered, American "pedagogies of difference" in a setting where many students were struggling with the fact that English, not their native Afrikaans or Xhosa, is now the language of the classroom. They did not want their "difference celebrated" as the phrase commonly went in the United States-they wanted to get on with learning the English-dominated academic game they had signed up for.

\section{They wanted mostly to learn the secrets of intellectual upward mobility in an English-language dominated Western educational system. And they were right, as English-language MA's are the coin of the realm for careers in higher education.}


I was forced to rethink my own pedagogies of student engagement at home. How much had I always relied for my technique on working with more privileged students, those in no need of training in basic academic skills? How could so-called interactive pedagogies genuinely bridge the huge gaps here of learning and experiences, building on and extending rather than stifling all the valuable things these students already knew?

When I was asked to help an African man with the organization of his Master's Thesis, he apologized for his stupidity and his poor English. English was his fifth language, after four African languages and Afrikaans. Some stupidity! Yet these students minimized their own achievements. They wanted mostly to learn the secrets of intellectual upward mobility in an English-language dominated Western educational system. And they were right, as English-language MA's are the coin of the realm for careers in higher education.

South Africans admired America, knew about the American Civil Rights movement and revered Martin Luther King. One day, we went to the funeral of a former ANC activist who had done a lot of community work in one of the townships. At the service the township choir sang The Battle Hymn of the Republic: "His Truth is marching on."

And yet the American empire that I represented in spite of myself, and wanted to resist every chance I could, that American empire was not that big an issue for the people I met. In February of 2003 it looked as if the United States was about to invade Iraq. Seething with outrage I went to a meeting at the University of Cape Town (UTC) to plan a demonstration, and offered to pass out leaflets and help to build the crowd. Instead I was told, "Look, we agree about the U.S. invasion, but it's not really our issue. It's your issue. We are much more worried about AIDS, you know."

At the demonstration a week later, the turnout was meager. Most of the local demonstrators were Cape Muslims, members of a local community formerly classified as Coloured, who objected to the invasion of another Muslim country. I made a sign, "Americans against the War," and got a lot of smiles and some interesting conversations. However the turnout, on February $14^{\text {th }}$, was about one tenth the size of the one the next day, February $15^{\text {th }}$, a Valentine's Day rally to demand that Mbeki start treating AIDS. We were swept up in a vast crowd of thousands and thousands of people, mostly Black, the masses we had looked for in vain the day before. It's a big mistake to take for granted that "our" causes are universal.

Most important for my own work, there was the issue of faculty recruitment, curriculum and research priorities for the new South Africa. My research project at home was an investigation, with Mary Kay Tetreault of Portland State University, of the recruitment of women and faculty of color at three major American universities. ${ }^{1}$ Thus my main activity at the EPU was to help Betty in carrying out a research grant from the national government to study the "deracialization" of higher education faculties at several local institutions: UWC; UTC, the preeminent university in Cape Town, formerly White and English speaking; and
Stellenbosch University, located in a nearby suburb, formerly White and Afrikaans speaking. (Note the term "deracialization"-but I was getting used to it.) Beyond collecting statistics on the current numbers of Black, Coloured and Indian faculty, she planned to interview key people at each place about their experiences in the institution. We decided to conduct as many as possible of these interviews together, comparing notes and writing up the findings.

I quickly learned that the reason there were and are so few Black African faculty members in any of these places is that until the 1990 s so few Blacks were allowed any education at all beyond elementary school. Predictably, the few Black faculty we met were from Uganda, or Kenya, or Zimbabwe. Betty and I interviewed three or four of these faculty members in each place, all of whom told us how isolated and beleaguered they felt. They faced the same problems of American faculty of color. They felt responsible for the students of color, who were suddenly the majority at all three schools. They were the tokens on faculty committees and absent on the important ones, like hiring. They were underrepresented in permanent posts, overrepresented in temporary ones. Perhaps most importantly, they often lacked the time, training or experience to create a research agenda for themselves. In one interview a senior Coloured professor at Stellenbosch told us how he instructed his Ph.D. students and newly hired colleagues in constructing a personal research agenda.

"I do this for everyone, but it's really for the Black recruits. I take them away for the weekend and give them a crash course in academic research. I tell them, first, find a research topic that is yours, and only yours. Then publish in a local newspaper or journal, write op-eds, that kind of thing. Then write a few articles and publish them in national journals. Then, if your field demands it, turn your dissertation into a book. Finally, go for international publications, and your reputation is made. Start small. Get your own topic."

This kind of trenchant advice about the research process seemed an excellent example of identifying and supplying the kind of cultural capital needed by newcomers to the norms of academic life. When I left, Betty was still collecting data; her final report recommended increased attention and funding for the recruitment, mentoring and support of Black, Coloured and Indian faculty on all three campuses. In my subsequent visits to Cape Town and UWC, I could see very little progress along these lines. I reminded myself that the few significant changes Tetreault and I found in the racial and gender composition of our universities had taken 40 years.

Some of the people we interviewed also spoke of the challenges of selecting research topics. Many investigators in the social sciences and education were on government grants, examining various aspects of the new society-in the case of the EPU, literacy rates, adult education, the location of new school buildings and the like. In some areas, however, research followed a longstanding Western colonial agenda. For example, at the University of the Western Cape, in spite of the fact that tropical diseases are 
a huge problem in Southern Africa, there was more money to study Western diseases than there is to study health issues closer to hand. I met three people, all women, one Coloured and two Indian, who were researching native medicines and healing practices. They were adjunct instructors with no job security and no prospects for it. "We are told what we are doing is not science," one said to me.

Many of the Coloured and Black colleagues we spoke to ruefully bemoaned the complete lack of attention to Black African history, literature, scientific and religious traditions in the university curriculum, in spite of the fact that their student bodies had drastically changed and were mostly Black and Coloured now, and even though the phrase "Proudly South African," meaning the new, inclusive multicultural society, was the phrase on everyone's lips, on every poster, and on every logo in sight.

\section{Many of the Coloured and Black colleagues we spoke to ruefully bemoaned the complete lack of attention to Black African history, literature, scientific and religious traditions in the university curriculum.}

Betty and I thought we might write an article comparing Stanford University and the University of Cape Town around their common curriculum reform efforts. Stanford University had successfully initiated a multicultural requirement a decade earlier, in 1989. At the University of Cape Town a similar initiative was begun in the late 1990s, to incorporate topics and concerns from an Africanist perspective into some aspects of the undergraduate curriculum. One theme was a reconception of African history that challenged the idea of the colonial era as bringing "civilization" to Africa. But entrenched senior faculty at UCT rejected the project out of hand, as many American universities had once done. Its most famous proponent, the prominent Africanist scholar Mahmoud Mamdani, gave up his administrative position at UTC in disappointment and disgust. He subsequently left Cape Town altogether and decamped to Columbia University in New York.

Again and again I was to run into this paradox of a brand new African nation, brimming with potential to build a truly Afrocentric university system, seeking nothing more than renewed contact and parity with the West. After all those years of isolation from their international peers, many of the South African professoriate, mostly White but by no means all, were starving for Western contacts, Western publishing contracts, tickets and travel to Western academic conferences. Upward mobility in the new South Africa is tied to, even identified with, Westernization.

At least in part, of course, this was and is a question of legitimization and self-respect. With such a long history of colonial dismissal and degradation it's hard to retrieve "native" concerns when they are not credentialed in traditional ways. Such delegitimization has long been the lot of Women's Studies, African American Studies and many other such fields in the United States as well. Faculty have had to "prove" that they, and their academic fields, are as rigorous as those in the mainstream, before they achieve academic legitimacy. These issues of "quality" and "excellence" still haunt the diversity agenda at home.

Yet the attachment to traditional European knowledges in South Africa, to the exclusion of African ones, kept puncturing my dream of a "proudly South African" intellectual community. Seeking a course in African Literature at the University of Cape Town, I found no one at first who was teaching it. I learned instead that the English Department was offering a course on Derrida. (UCT, a formerly all white English-speaking university, now has over $50 \%$ Black and Coloured students but still an almost all-white faculty.) When I asked someone about this I was told, "Why shouldn't we teach Derrida if they teach it at Columbia and Oxford? We are a world class university too." When I finally did find a course on African literature all seven students were foreigners like me, and the teacher was a visiting professor from Uganda. It felt like a last-minute add-on and was not a requirement in the English department. I felt like a tourist taking it.

Looking at my experiences in 2003 again, ten years later, the feelings of dislocation they produced in me make a kind of fractured sense, one observer's fuzzy expectations confronting a confusing reality. I have made many subsequent visits to Cape Town and to my old friends there, every other year since 2003, amid my increasingly clearer realization that neither in South Africa nor in the United States, despite an ever more visible Black middle class in each country, has racial equality any kind of a chance without economic and political equality and justice.

\section{In my longing to see my own ideals of racial progress reflected in the "New South Africa" I had also been looking into a broken mirror. The South Africa of university life was, and is, fissured and split between the two severe imperatives of catching up with the outside world and discovering, or rediscovering, its own cultural, political and economic identity as a flagship state of the new postcolonial Africa.}

As in many other countries, most of South Africa's people are victims of the dictates of the World Bank and the International Monetary Fund, as the government sacrifices progressive economic policies to a place in the world's free market system. Some of the main beneficiaries, as elsewhere, have been a growing and prosperous Black (and Coloured and Indian) middle class, and government policy sees the role of education in general, and higher education in particular, as equipping 
this new middle class with the skills to run a technologically modern economy and society. And yet Black unemployment in particular has not gone much below $70 \%$ in the twenty years since Mandela was elected President in 1994. Whether the country's membership in this system of international exploitation has given them their "world-class university" system is a different question.

In my longing to see my own ideals of racial progress reflected in the "New South Africa" I had also been looking into a broken mirror. The South Africa of university life was, and is, fissured and split between the two severe imperatives of catching up with the outside world and discovering, or rediscovering, its own cultural, political and economic identity as a flagship state of the new postcolonial Africa. Becoming a prominent Western university or locating and disseminating an indigenous African literature? Working on stem cells like everyone else or exploring the biological bases of longstanding successful local healing practices? And above and beneath all of this is the persistence of African poverty, the world of the townships. There seemed little room for the ideas of some of my friends there, those who want to build their world-class university on the basis of rather than in spite of an African literature, history, politics and science.

Ultimately, after all, what could an American academic have to offer, who herself is the beneficiary, and unwilling representative of, the hegemonic knowledges and practices sought by her hosts? "We want what you have," even though what I have, I see as representing the new world order of global capitalism, a system deeply damaging to the South Africa of racial harmony and economic equality that I dream of. And, ultimately had South Africa itself, for me, been a stand-in all along for a United States of America of racial harmony and economic equality that I now understand I will never see?

\section{Notes}

1 Published as Frances Maher and Mary Kay Tetreault, Privilege and Diversity in the Academy, Routledge, 2006. 